\title{
Unintentional injury mortality and external causes in Canada from 2001 to 2007
}

\author{
Y. Chen, PhD (1); F. Mo, PhD (2); Q. L. Yi, PhD (1); Y. Jiang, MSc (2); Y. Mao, PhD (2)
}

This article has been peer reviewed.

\begin{abstract}
Introduction: To understand the distribution pattern and time trend of unintentional injury mortalities is crucial in order to develop prevention strategies.
\end{abstract}

Methods: We analyzed vital statistics data from Canada (excluding Quebec) for 2001 to 2007. Mortality rates were age- and sex-standardized to the 2001 Canadian population. An autoregressive model was used for time-series analysis.

Results: Overall mortality rate steadily decreased but unintentional injury mortality rate was stable over the study period. The three territories had the highest mortality rates. Unintentional injury deaths were less common in children than in youths/adults. After 60 , the mortality rate increased steadily with age. Males were more likely to die of unintentional injury, and the male/female ratio peaked in the 25- to 29-year age group. Motor vehicle crashes, falls and poisoning were the three major causes. There was a substantial year after year increase in mortality due to falls. Deaths due to motor vehicle crashes and drowning were more common in summer months, and deaths caused by falls and burns were more common in winter months.

Conclusion: The share of unintentional injury among all-cause mortality and the mortality from falls increased in Canada during the period 2001 to 2007.

Keywords: age standardization, burn, Canada, consumer product, drowning, fall, mortality, poisoning, unintentional injury, suffocation, vehicle traffic crash, vital statistics

\section{Introduction}

Injuries are among the leading causes of death and disabilities worldwide. ${ }^{1}$ They represent about $16 \%$ of the global burden of disease $\mathrm{e}^{2}$ and are the leading cause of death in people aged under 60 years. $^{3}$ In 2004, World Health Organization estimated that injuries caused over 5 million deaths per year, of which 3.9 million were unintentional. ${ }^{4}$ Compared to many other diseases, injuries affect more young people, and therefore result in more years of life lost. ${ }^{1}$ In Canada, the total economic burden of injury was about $\$ 20$ billion in
2004, of which $\$ 16$ billion was as a result of unintentional injuries. ${ }^{5}$

Unintentional injury is any injury that is not caused on purpose or with intention to harm. Since not all unintentional injuries are random events and some of them can be prevented, it is not usually appropriate to use the word "accident" to define unintentional injury. Unintentional injury can be further classified according to external causes such as motor vehicle collisions, falls, poisoning, drowning, suffocations and so on. ${ }^{6}$ Unintentional injuries may be work-related or sports-related.
Different types of unintentional injury may have unique patterns in different subpopulations, for example, motor vehicle crashes are most common among young people ${ }^{7}$ while falls are more likely to cause a fatal outcome among the elderly. ${ }^{8}$ Monitoring the changing patterns of overall and cause-specific unintentional injury mortalities gathers information essential to developing new programs on unintentional injury prevention and intervention and modifying existing ones. In this study, we conducted a descriptive analysis of vital statistics data to investigate the distribution patterns and time trends of overall and cause-specific unintentional injury mortalities in Canada (excluding Quebec).

\section{Methods}

The study was based on mortality data from the Canadian Vital Statistics Death Database (excluding deaths registered in the province of Quebec, since these were not available on the Data Extraction and Analysis System, Public Health Agency of Canada) for the period from January 1, 2001, to December 31, 2007. Death statistics are based on information abstracted and compiled from death certificates, and are provided to Statistics Canada by the vital statistics registrars in each province or territory. The mortality data in this analysis are coded using the International Classification of Diseases, 10th Revision (ICD-10), in which external causes are classified under a series of alphanumeric codes, V01-Y98. These codes were used to identify unintentional injury deaths (ICD10: V01-X59, Y85-Y86) and unintentional

Author references:

1. Department of Epidemiology and Community Medicine, University of Ottawa, Ottawa, Ontario, Canada

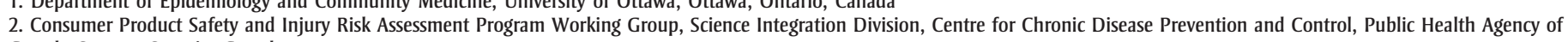
Canada Ottawa, Ontario, Canada

Correspondence: Yue Chen, Department of Epidemiology and Community Medicine, Faculty of Medicine, University of Ottawa, 451 Smyth Road, Ottawa, ON K1H 8M5;

Tel.: 613 562-5800 ext. 8287; Fax: 613 562-5465; Email: ychen@uottawa.ca 
injury deaths by cause including motor vehicle traffic crashes (V02-V04 [.9], V09.2, V12-V14 [.3-.9], V19 [.4-.6], V20V28 [.3-.9], V29 [.4-.9], V30-V79 [.4-.9], V80 [.3-.5], V81-V82 [.1], V83-V86 [.0-.3], V87 [.0-.8], V89.2); pedal cycle (ICD-10: V10-V14, V16-V19); pedestrian (trafficrelated) (ICD-10: V02-V04 [.1], V09.2, V09.3); recreation boating (ICD-10: V90.2V90.8, V91.2-V91.8, V92.2-V92.8, V93.2V93.8, V94.2-V94.8); drowning (ICD-10: V90, V92, W65-W74); falls (ICD-10: W00W19); burns or fire (ICD-10: W85-W91, X00-X19); suffocations (ICD-10: W75W84); poisoning (ICD-10: X40-X49) and other unintentional causes.

We took annual population estimates from Statistics Canada's annual demographic statistics. $^{9,10}$ Age- and sex-standardized mortality rates were calculated using the direct method with reference to the 2001 Canadian population. For each province and for the three territories (Northwest Territory, Yukon and Nunavut) combined, average overall mortality rates were calculated for the 7-year study period, that is, the total number of deaths during the period divided by the sum of the annual populations, which is equivalent to a weighted average of annual rates using the annual population as a weight.

To explore time trends for unintentional injury mortality rates from 2001 to 2007 and seasonal pattern for cause-specific unintentional injury mortalities in males and females, we conducted time-series analysis. The mortality rates were calculated by using average annual population as the denominator since there were no monthly population estimates. Because the numbers of death per month were small and could not be further stratified by age, we conducted age and sex-standardization by using the ratios of annual standardized versus crude rates (crude monthly rate $\times$ standardized/crude mortality for the year). The adjusted monthly rates were then plotted to visually display their time trends and seasonal patterns. Autoregressive models were fitted to determine the associations of secular year and month with various unintentional injury mortalities. In the models, the first order autocorrelation was considered, with monthly rates being dependent vari- ables and year and month indicators being independent variables.

All analyses were conducted using SAS version 9.1 statistical software (SAS Institute Inc., Cary, NC, US).

\section{Results}

There were a total of 51178 deaths due to unintentional injuries, which accounted for $4.2 \%$ of all deaths in Canada excluding Quebec during the study period from 2001 to 2007. The age- and sex-standardized mortality for all causes steadily decreased from 702 per 100000 in 2001 to 631 per 100000 in $2007(p<.001)$ while the mortality due to unintentional injuries was relatively stable year after year $(p=.571)$. As a result, the proportion of uninten- tional injury mortality versus all mortality increased significantly ( $p=.003$ ) in the 7year period. Males accounted for $61.1 \%$ of all unintentional injury deaths. However, males and females had similar time trends for unintentional injury mortality, overall mortality (all causes combined) and their ratio (Table 1 ).

After age- and sex-standardization, the three territories combined had the highest overall mortality (842.3 per 100 000) and unintentional injury mortality (69.1 per 100 000) (Table 2). British Columbia had the lowest overall mortality (626.8 per 100 000) while Newfoundland and Labrador had the lowest mortality due to unintentional injuries (24.8 per 100 000). The unintentional injury mortality for the three territories was almost triple that of

TABLE 1

Crude and standardized mortality by calendar year, total and by sex, Canada (excluding Quebec), 2001-2007

\begin{tabular}{|c|c|c|c|c|c|}
\hline \multirow{2}{*}{$\begin{array}{l}\text { Calendar } \\
\text { year }\end{array}$} & \multicolumn{2}{|c|}{ Crude mortality } & \multicolumn{3}{|c|}{ Standardized mortality } \\
\hline & $\begin{array}{l}\text { All causes, } \\
\text { per } 100000\end{array}$ & $\begin{array}{c}\text { Unintentional } \\
\text { injury, } \\
\text { per } 100000\end{array}$ & $\begin{array}{l}\text { All causes, } \\
\text { per } 100000\end{array}$ & $\begin{array}{l}\text { Unintentional } \\
\text { injury, } \\
\text { per } 100000\end{array}$ & $\begin{array}{l}\text { Unintentional } \\
\text { injury/All } \\
\text { causes, \% }\end{array}$ \\
\hline \multicolumn{6}{|l|}{ Total } \\
\hline 2001 & 701.8 & 28.7 & 702.1 & 28.7 & 4.09 \\
\hline 2002 & 704.3 & 29.9 & 692.3 & 29.6 & 4.28 \\
\hline 2003 & 710.3 & 29.5 & 685.3 & 28.8 & 4.20 \\
\hline 2004 & 702.2 & 28.7 & 664.6 & 27.7 & 4.27 \\
\hline 2005 & 708.5 & 30.1 & 656.8 & 28.6 & 4.35 \\
\hline 2006 & 699.2 & 30.5 & 633.6 & 28.5 & 4.50 \\
\hline 2007 & 709.7 & 32.0 & 631.0 & 29.7 & 4.71 \\
\hline \multicolumn{6}{|l|}{ Male } \\
\hline 2001 & 725.0 & 36.4 & 879.5 & 39.9 & 4.54 \\
\hline 2002 & 720.3 & 37.1 & 857.7 & 40.6 & 4.73 \\
\hline 2003 & 729.5 & 36.2 & 851.2 & 39.3 & 4.62 \\
\hline 2004 & 718.7 & 35.2 & 824.1 & 37.8 & 4.59 \\
\hline 2005 & 722.6 & 37.3 & 811.2 & 39.6 & 4.88 \\
\hline 2006 & 715.1 & 36.8 & 783.2 & 38.5 & 4.92 \\
\hline 2007 & 725.9 & 39.0 & 778.3 & 40.4 & 5.19 \\
\hline \multicolumn{6}{|l|}{ Female } \\
\hline 2001 & 679.1 & 21.2 & 572.7 & 18.5 & 3.23 \\
\hline 2002 & 688.5 & 22.8 & 571.3 & 19.7 & 3.45 \\
\hline 2003 & 691.4 & 22.9 & 564.3 & 19.3 & 3.42 \\
\hline 2004 & 686.0 & 22.4 & 547.8 & 18.4 & 3.36 \\
\hline 2005 & 694.5 & 23.0 & 650.3 & 18.9 & 2.91 \\
\hline 2006 & 683.5 & 24.3 & 626.4 & 19.4 & 3.10 \\
\hline 2007 & 693.8 & 25.0 & 624.7 & 20.0 & 3.20 \\
\hline
\end{tabular}

a Standardized according to the entire 2001 Canadian population. 
Newfoundland and Labrador. Ontario also had a low unintentional injury mortality (26.3 per 100 000), which was similar to Newfoundland and Labrador, but all-cause mortality was very different in the two provinces, 655.9 per 100000 in Ontario versus 802.9 per 100000 in Newfoundland and Labrador. The differences between the other provinces were relatively small for both all-cause mortality and unintentional injury mortality (Table 2). Table 2 also shows that the unintentional injury mortality and the ratio of unintentional injury versus all-cause mortalities were higher in males than in females across all provinces/ territories.

Unintentional injury deaths were less common among children $(<7$ per 100 000) than among youths and adults (Table 3). Unintentional injury mortality was generally similar for those aged 15 to 59 years (28.5-37.7 per 100000 in males and 8.5-12.7 per 100000 in females). After age 60 years, mortality increased steadily with age from 35.3 per 100000 in the 60- to 64-year age group to 801.0 per 100000 in the 90-year-plus age group in men and from 14.4 to 663.1 per 100000 in women. In all the age groups, males were more likely to die of unintentional injuries (Table 3). The male to female mortality ratio increased with age after 5 to 9 years (1.34), peaked at 25 to 29 years (3.76) and then steadily decreased with age. Table 3 also shows that of unintentional injury deaths from identified causes, motor vehicle traffic crashes were most common in males, with a mortality rate of 10.2 per 100 000, followed by falls (7.7 per 100 000) and poisoning (5.1 per 100000$)$. In females, the first three identified causes for unintentional injury death were falls, motor vehicle traffic crashes and poisoning with the mortality rates being 7.9, 4.5 and 2.2 per 100 000, respectively. Cause-specific unintentional injury mortalities were all higher in males than in females except for fall mortality (Table 3). Overall, falls accounted for $26 \%$ of all unintentional injury deaths, motor vehicle traffic crashes for $24 \%$ and poisoning for $12 \%$ (Figure 1).

Although unintentional injury mortality increased sharply after 60 years of age, it comprised a much higher proportion of all deaths in younger age groups

TABLE 2

Average mortality by province/territory, Canada (excluding Quebec), total and by sex, 2001-2007

\begin{tabular}{|c|c|c|c|c|c|}
\hline \multirow[t]{2}{*}{ Province } & \multicolumn{2}{|c|}{ Crude mortality } & \multicolumn{3}{|c|}{ Standardized mortality } \\
\hline & $\begin{array}{l}\text { All causes, } \\
\text { per } 100000\end{array}$ & $\begin{array}{c}\text { Unintentional } \\
\text { injury, } \\
\text { per } 100000\end{array}$ & $\begin{array}{l}\text { All causes, } \\
\text { per } 100000\end{array}$ & $\begin{array}{l}\text { Unintentional } \\
\text { injury, } \\
\text { per } 100000\end{array}$ & $\begin{array}{l}\text { Unintentional } \\
\text { injury/All } \\
\text { causes, \% }\end{array}$ \\
\hline \multicolumn{6}{|l|}{ Total } \\
\hline British Columbia & 715.7 & 32.1 & 626.8 & 30.1 & 4.80 \\
\hline Alberta & 582.4 & 27.8 & 660.7 & 28.7 & 4.34 \\
\hline Saskatchewan & 896.0 & 42.5 & 693.8 & 37.5 & 5.41 \\
\hline Manitoba & 843.7 & 38.1 & 720.3 & 34.7 & 4.82 \\
\hline Ontario & 680.7 & 27.0 & 655.9 & 26.3 & 4.01 \\
\hline New Brunswick & 831.2 & 38.3 & 713.2 & 35.3 & 4.95 \\
\hline Nova Scotia & 871.2 & 35.6 & 733.9 & 31.8 & 4.33 \\
\hline $\begin{array}{l}\text { Prince Edward } \\
\text { Island }\end{array}$ & 837.9 & 35.5 & 703.7 & 32.4 & 4.60 \\
\hline $\begin{array}{l}\text { Newfoundland } \\
\text { and Labrador }\end{array}$ & 841.0 & 25.2 & 802.9 & 24.8 & 3.09 \\
\hline Territories $^{\mathrm{b}}$ & 396.5 & 52.3 & 842.3 & 69.1 & 8.20 \\
\hline \multicolumn{6}{|l|}{ Male } \\
\hline British Columbia & 741.7 & 42.0 & 769.8 & 42.5 & 5.52 \\
\hline Alberta & 603.3 & 37.3 & 822.0 & 41.0 & 4.99 \\
\hline Saskatchewan & 926.4 & 53.3 & 881.0 & 52.8 & 5.99 \\
\hline Manitoba & 850.1 & 44.9 & 903.0 & 46.6 & 5.16 \\
\hline Ontario & 691.7 & 31.5 & 808.1 & 35.0 & 4.33 \\
\hline New Brunswick & 856.7 & 49.8 & 906.6 & 50.9 & 5.61 \\
\hline Nova Scotia & 892.3 & 43.1 & 921.3 & 44.3 & 4.81 \\
\hline $\begin{array}{l}\text { Prince Edward } \\
\text { Island }\end{array}$ & 852.6 & 43.4 & 895.2 & 45.3 & 5.06 \\
\hline $\begin{array}{l}\text { Newfoundland } \\
\text { and Labrador }\end{array}$ & 905.2 & 32.9 & 1022.9 & 34.7 & 3.39 \\
\hline Territories $^{\mathrm{b}}$ & 486.9 & 74.8 & 1023.9 & 92.1 & 9.00 \\
\hline \multicolumn{6}{|l|}{ Female } \\
\hline British Columbia & 690.0 & 22.3 & 520.0 & 18.6 & 3.58 \\
\hline Alberta & 561.0 & 18.1 & 543.9 & 17.6 & 3.24 \\
\hline Saskatchewan & 866.1 & 31.9 & 557.7 & 23.5 & 4.21 \\
\hline Manitoba & 837.5 & 31.4 & 587.7 & 24.4 & 4.15 \\
\hline Ontario & 670.1 & 22.7 & 544.7 & 18.7 & 3.43 \\
\hline New Brunswick & 806.5 & 27.2 & 572.9 & 21.4 & 3.74 \\
\hline Nova Scotia & 851.2 & 28.4 & 596.4 & 20.7 & 3.47 \\
\hline $\begin{array}{l}\text { Prince Edward } \\
\text { Island }\end{array}$ & 823.9 & 28.0 & 566.9 & 20.1 & 3.55 \\
\hline $\begin{array}{l}\text { Newfoundland } \\
\text { and Labrador }\end{array}$ & 778.6 & 17.8 & 647.5 & 15.3 & 2.36 \\
\hline Territories $^{\mathrm{b}}$ & 300.5 & 28.5 & 695.6 & 45.2 & 6.50 \\
\hline
\end{tabular}

a Standardized according to the entire 2001 Canadian population.

b Yukon, Northwest Territory, Nunavut.

(Table 4), peaking at age 15 to 19 years $(45.2 \%)$ for both males $(46.7 \%)$ and females $(41.8 \%)$, then gradually decreasing (Table 4).
We investigated major external causes for unintentional injury mortality separately, including motor vehicle traffic crashes, falls, poisoning, pedestrian (traffic- 
TABLE 3

Mortality and male to female ratio for mortality due to unintentional injury by age and external causes, Canada (excluding Quebec), 2001-2007

\begin{tabular}{|c|c|c|c|}
\hline & \multicolumn{2}{|c|}{$\begin{array}{l}\text { Mortality, } \\
\text { per } 100000\end{array}$} & \multirow[t]{2}{*}{$\begin{array}{c}\text { Ratio } \\
\text { Male:Female }\end{array}$} \\
\hline & Male & Female & \\
\hline \multicolumn{4}{|l|}{$\begin{array}{l}\text { Age group, } \\
\text { years }\end{array}$} \\
\hline $0-4$ & 7.5 & 5.3 & 1.42 \\
\hline $5-9$ & 4.3 & 3.2 & 1.34 \\
\hline $10-14$ & 6.2 & 3.5 & 1.77 \\
\hline 15-19 & 29.0 & 12.0 & 2.42 \\
\hline $20-24$ & 37.7 & 12.1 & 3.12 \\
\hline $25-29$ & 32.0 & 8.5 & 3.76 \\
\hline $30-34$ & 28.5 & 8.6 & 3.31 \\
\hline $35-39$ & 30.4 & 9.8 & 3.10 \\
\hline $40-44$ & 33.1 & 10.6 & 3.12 \\
\hline $45-49$ & 34.8 & 11.9 & 2.92 \\
\hline $50-54$ & 33.3 & 11.5 & 2.90 \\
\hline $55-59$ & 33.3 & 12.7 & 2.62 \\
\hline $60-64$ & 35.3 & 14.4 & 2.45 \\
\hline $65-69$ & 42.8 & 21.0 & 2.04 \\
\hline $70-74$ & 56.9 & 32.3 & 1.76 \\
\hline $75-79$ & 98.0 & 61.4 & 1.60 \\
\hline $80-84$ & 187.2 & 122.5 & 1.53 \\
\hline $85-89$ & 362.9 & 271.4 & 1.33 \\
\hline$\geq 90$ & 801.0 & 663.1 & 1.21 \\
\hline \multicolumn{4}{|l|}{$\begin{array}{l}\text { External } \\
\text { causes }\end{array}$} \\
\hline $\begin{array}{l}\text { Motor vehicle } \\
\text { crashes }\end{array}$ & 10.2 & 4.5 & 2.3 \\
\hline $\begin{array}{l}\text { Pedestrian } \\
\text { (traffic-related) }\end{array}$ & 1.3 & 0.8 & 1.6 \\
\hline Pedal cycle & 0.4 & 0.1 & 5.4 \\
\hline $\begin{array}{l}\text { Recreation } \\
\text { boating }\end{array}$ & 0.2 & 0.0 & 10.4 \\
\hline Drowning & 1.5 & 0.4 & 4.3 \\
\hline Falls & 7.7 & 7.9 & 1.0 \\
\hline Burns & 1.1 & 0.6 & 1.9 \\
\hline Suffocation & 1.6 & 1.1 & 1.4 \\
\hline Poisoning & 5.1 & 2.2 & 2.3 \\
\hline Others & 7.9 & 5.6 & 1.4 \\
\hline
\end{tabular}

related), drowning, burns, and suffocation in males (Table 5; Figure 2) and in females (Table 6; Figure 3). There was a substantial year after year increase in mortality as a result of injuries due to falls in both males $(p<.01)$ and females $(p<.01)$. For other type of injuries, agestandardized mortalities either decreased
FIGURE 1

Proportion of unintentional injury deaths by cause in Canada excluding Quebec, 2001-2007

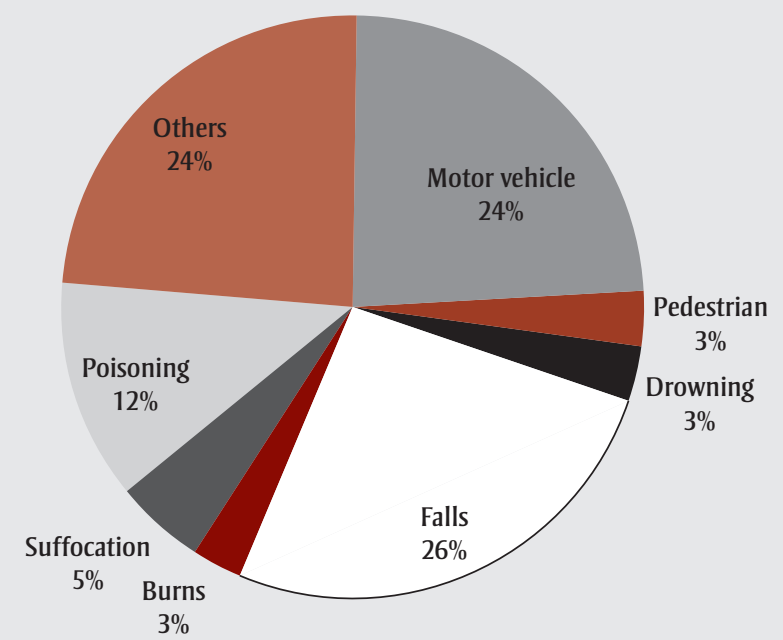

slightly (burns and drowning in males, mortality. The unintentional injury versus motor vehicle crashes and burns in females) or showed no significant changes. The risk of death caused by motor vehicle traffic crashes and drowning was significantly higher in summer months and was more marked in males than females. Deaths caused by falls and burns were more common in winter months. More poisoning deaths could be seen in March and April $(p<.05)$ and pedestrian accident deaths in September and October $(p<.05)$ and November and December $(p<.01)$ when compared with January and February. There was no significant difference between the month periods for suffocation.

\section{Discussion}

Our study demonstrated that age- and sexstandardized mortality from all unintentional injuries was stable during the 7-year study period whereas overall mortality declined approximately $10 \%$ and the proportion of unintentional injury versus overall mortalities increased from $4.1 \%$ to $4.7 \%$. This indicated that the share of unintentional injury in all causes for mortality is on the increase in Canada. All unintentional injury mortality in males, as well as cause-specific injury mortalities but with the exception of fall mortality, exceeded those in females.

The three territories had the highest overall mortality and unintentional injury overall mortality ratio was almost double in the three territories compared with the nine provinces. A previous populationbased case-control study conducted in the Northwest Territories demonstrated that being male, aged over 14 years, living in remote communities, living in the far north, and being Aboriginal were risk factors for injury mortality. ${ }^{11}$ There is a higher proportion of Aboriginal people in the territories compared with the rest of Canada. A study conducted among Albertan children showed that Aboriginal children had a significantly higher risk for both intentional and unintentional injury deaths. ${ }^{12}$ Injury mortality rates among Indigenous people in the United States and Australia are approximately 2 to 3 times greater than rates for non-Aboriginal populations. ${ }^{13}$

Motor vehicle traffic crashes and falls were two major causes for unintentional injury deaths in Canada. The former was a more common cause in males than females and was a main reason for the markedly increased mortality from unintentional injuries in youths and young adults. The mortality due to motor vehicle traffic crashes changed little year after year during the study period in males and declined slightly in females. However, the data showed a clear seasonal pattern with and more so in males than in females. During the traditional summer vacation a significantly increased risk in summer 
TABLE 4

Overall and unintentional injury mortality (per 100 000) by age and sex, Canada (excluding Quebec), 2001-2007

\begin{tabular}{|c|c|c|c|c|c|c|c|c|c|}
\hline \multirow{2}{*}{$\begin{array}{l}\text { Age } \\
\text { group, } \\
\text { years }\end{array}$} & \multicolumn{3}{|c|}{ Total } & \multicolumn{3}{|c|}{ Male } & \multicolumn{3}{|c|}{ Female } \\
\hline & $\begin{array}{c}\text { All } \\
\text { causes, } \\
\text { per } \\
100000\end{array}$ & $\begin{array}{l}\text { Unintentional } \\
\text { injury, per } \\
100000\end{array}$ & $\begin{array}{l}\text { Unintentional } \\
\text { injury/All } \\
\text { causes, \% }\end{array}$ & $\begin{array}{c}\text { All } \\
\text { causes, } \\
\text { per } \\
100000\end{array}$ & $\begin{array}{l}\text { Unintentional } \\
\text { injury, per } \\
100000\end{array}$ & $\begin{array}{l}\text { Unintentional } \\
\text { injury/All } \\
\text { causes, \% }\end{array}$ & $\begin{array}{l}\text { All, per } \\
100000\end{array}$ & $\begin{array}{l}\text { Unintentional } \\
\text { injury, per } \\
100000\end{array}$ & $\begin{array}{l}\text { Unintentional } \\
\text { injury/All } \\
\text { causes, } \%\end{array}$ \\
\hline $0-4$ & 124.4 & 6.43 & 5.2 & 135.4 & 7.5 & 5.5 & 112.9 & 5.3 & 4.7 \\
\hline $5-9$ & 11.7 & 3.73 & 31.9 & 13.0 & 4.3 & 33.1 & 10.3 & 3.2 & 30.8 \\
\hline $10-14$ & 14.3 & 4.89 & 34.2 & 16.2 & 6.2 & 38.3 & 12.3 & 3.5 & 28.2 \\
\hline $15-19$ & 45.9 & 20.78 & 45.2 & 62.1 & 29.0 & 46.7 & 28.8 & 12.0 & 41.8 \\
\hline $20-24$ & 60.0 & 25.19 & 42.0 & 85.8 & 37.7 & 43.9 & 33.1 & 12.1 & 36.6 \\
\hline 25-29 & 58.5 & 20.35 & 34.8 & 82.6 & 32.0 & 38.7 & 34.0 & 8.5 & 25.0 \\
\hline $30-34$ & 69.6 & 18.60 & 26.7 & 92.1 & 28.5 & 30.9 & 46.8 & 8.6 & 18.4 \\
\hline $35-39$ & 95.9 & 20.12 & 21.0 & 122.1 & 30.4 & 24.9 & 69.4 & 9.8 & 14.1 \\
\hline $40-44$ & 140.6 & 21.91 & 15.6 & 174.9 & 33.1 & 18.9 & 106.0 & 10.6 & 10.0 \\
\hline $45-49$ & 221.8 & 23.35 & 10.5 & 272.9 & 34.8 & 12.8 & 170.8 & 11.9 & 7.0 \\
\hline 50-54 & 349.8 & 22.34 & 6.4 & 431.0 & 33.3 & 7.7 & 269.7 & 11.5 & 4.3 \\
\hline $55-59$ & 545.1 & 22.92 & 4.2 & 674.1 & 33.3 & 4.9 & 417.8 & 12.7 & 3.0 \\
\hline $60-64$ & 881.9 & 24.67 & 2.8 & 1092.7 & 35.3 & 3.2 & 677.4 & 14.4 & 2.1 \\
\hline $65-69$ & 1406.4 & 31.51 & 2.2 & 1751.8 & 42.8 & 2.4 & 1082.9 & 21.0 & 1.9 \\
\hline $70-74$ & 2270.4 & 43.83 & 1.9 & 2850.2 & 56.9 & 2.0 & 1755.2 & 32.3 & 1.8 \\
\hline $75-79$ & 3711.0 & 77.39 & 2.1 & 4684.2 & 98.0 & 2.1 & 2953.0 & 61.4 & 2.1 \\
\hline $80-84$ & 6157.3 & 147.78 & 2.4 & 7759.1 & 187.2 & 2.4 & 5130.4 & 122.5 & 2.4 \\
\hline $85-89$ & 10708.7 & 302.40 & 2.8 & 13173.0 & 362.9 & 2.8 & 9445.9 & 271.4 & 2.9 \\
\hline$\geq 90$ & 20590.7 & 700.09 & 3.4 & 23399.0 & 801.0 & 3.4 & 19562.0 & 663.1 & 3.4 \\
\hline
\end{tabular}

months, people may drive longer distances while on vacation and teens and young adults may have more opportunities to drive and ride in cars, ${ }^{1}$ and hence are more likely to be exposed to vehicleand traffic-related risk factors. Effective interventions on motor vehicle crashes are most important for reducing unintentional injury mortality among youths and young adults, especially for males.

Mortality due to falls was the only causespecific mortality that showed a steady increase during the study period, and it was slightly more common in females than males. Fall injury accounted for about one-third of all unintentional injury deaths in adults, and was the principal reason for the dramatic increase in mortality due to unintentional injury with age in the elderly. Worldwide, motor vehicle crashes account for $33 \%$ while falls only account for $11 \%$ of unintentional injury death, ${ }^{1}$ but in this study they

TABLE 5

Results of time-series analysis (autoregressive model) for major types of unintentional injury mortality (per 100 000) in males

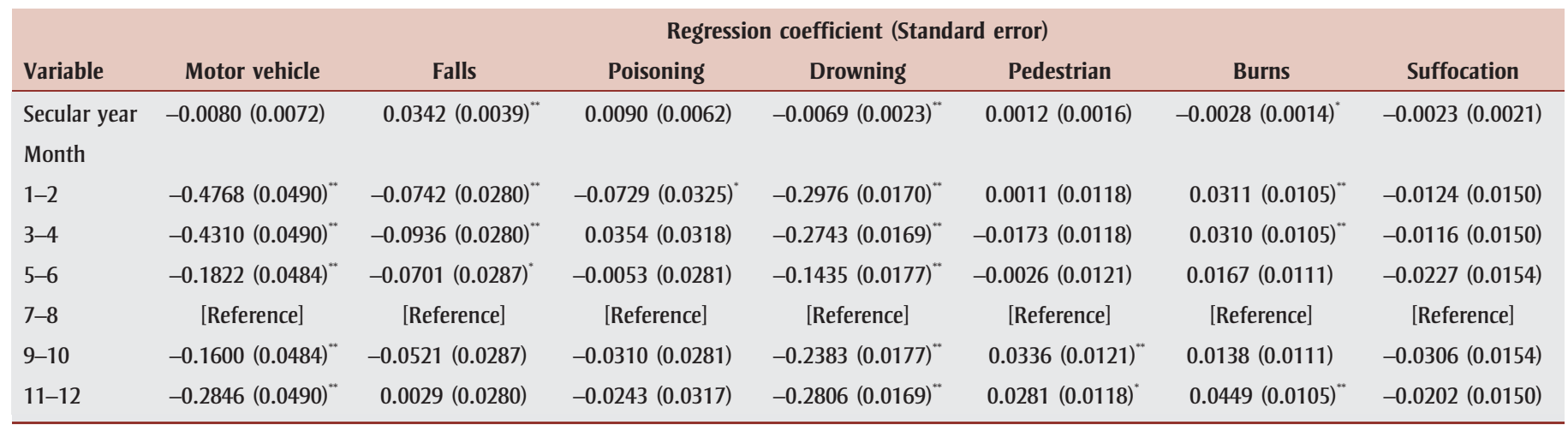

${ }^{*} p<.05$

** $p<.01$ 
FIGURE 2

Monthly standardized mortality due to different types of unintentional injury in males, Canada (excluding Quebec), 2001-2007

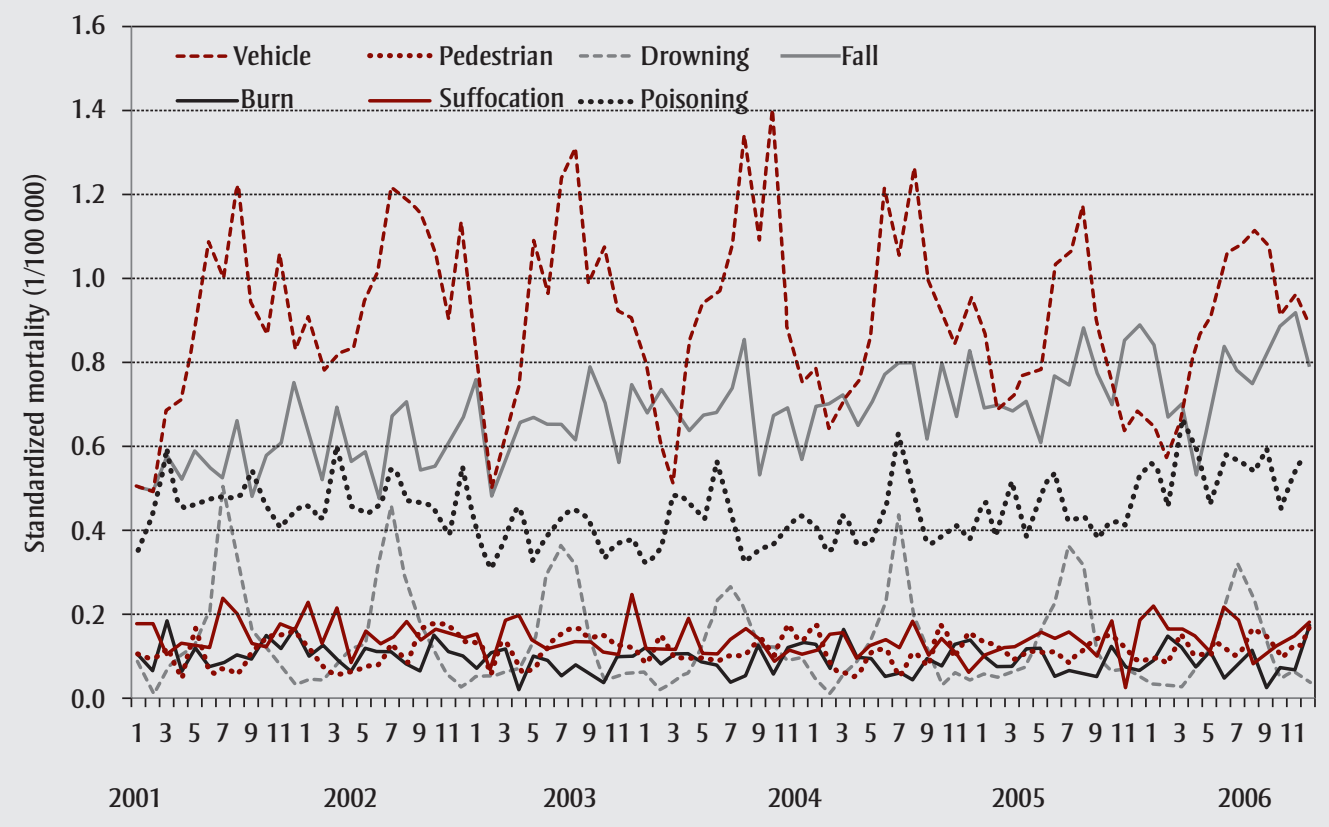

were $24 \%$ and $26 \%$, respectively (Figure 1). The aging process and low levels of bone mineral density are closely associated with the severity of an injury and the consequence of the fall. ${ }^{8,14-19}$ However, we do not know if aging and bone mineral density are the main reasons for the steady increase in mortality in the 7 -year study period. Other factors such as medication use, especially in older people, ${ }^{20}$ overweight and obesity, ${ }^{21,22}$ engagement in physical activity, ${ }^{23,24}$ utilization of medical products and day-to-day activities ${ }^{25-28}$ warrant further investigation for possible impact on the uptrend of mortality from falls in the Canadian population. Our study also showed a seasonal pattern for fall mortality, that is, it was the highest in November and December. One study from the United States found that fall injuries were associated with holiday decorating or related activities, which is also likely in our current context. ${ }^{29}$ Weather is probably another important reason. ${ }^{30,31}$

Poisoning was the third leading cause of unintentional injury mortality in Canada, and accounted for $14 \%$ of unintentional injury deaths in males and $10 \%$ in females (data not shown). Unintentional poisoning may be work-related, and other common agents are household chemicals and pesticides, medications and plants. ${ }^{32-35}$ Other causes of unintentional deaths such as drowning and burns were less common. Our data showed that deaths due to drowning most frequently happened in summer, and that males versus females and children versus adults accounted for a higher proportion of drowning-related deaths. Most drowning accidents are related to recreation or leisure. Our data also showed an increased mortality due to burns in winter but no seasonal variations for suffocation.

TABLE 6

Results of time-series analysis (autoregressive model) for major types of unintentional injury mortality (per 100 000 ) in females

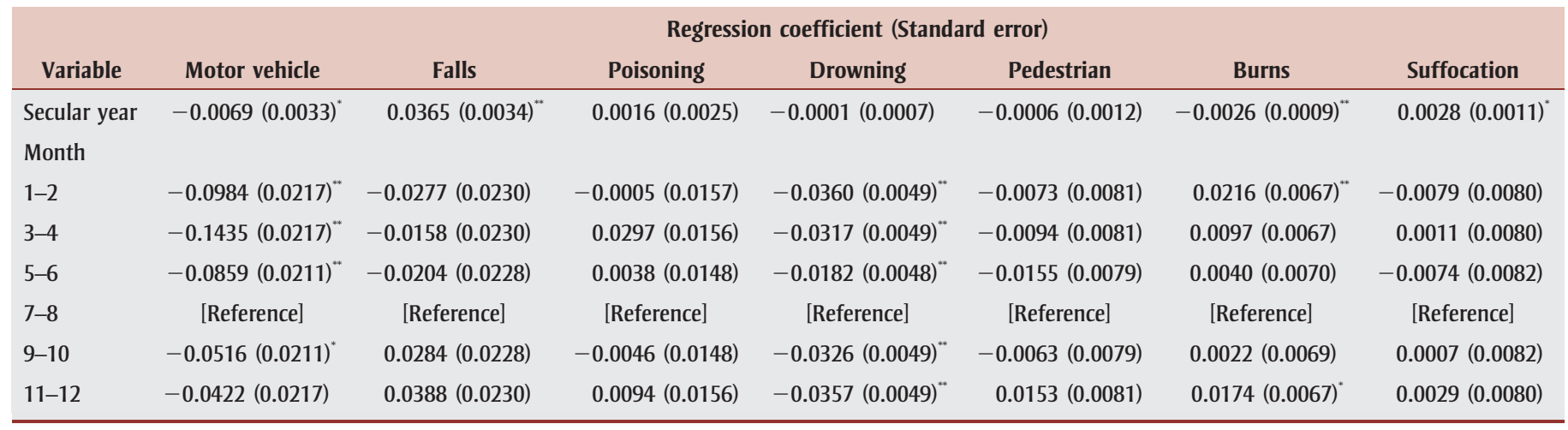

* $p$ value $<.05$

${ }^{* *} p$ value $<.01$ 
FIGURE 3

Monthly standardized mortality due to different types of unintentional injury in females in Canada (excluding Quebec), 2001-2007

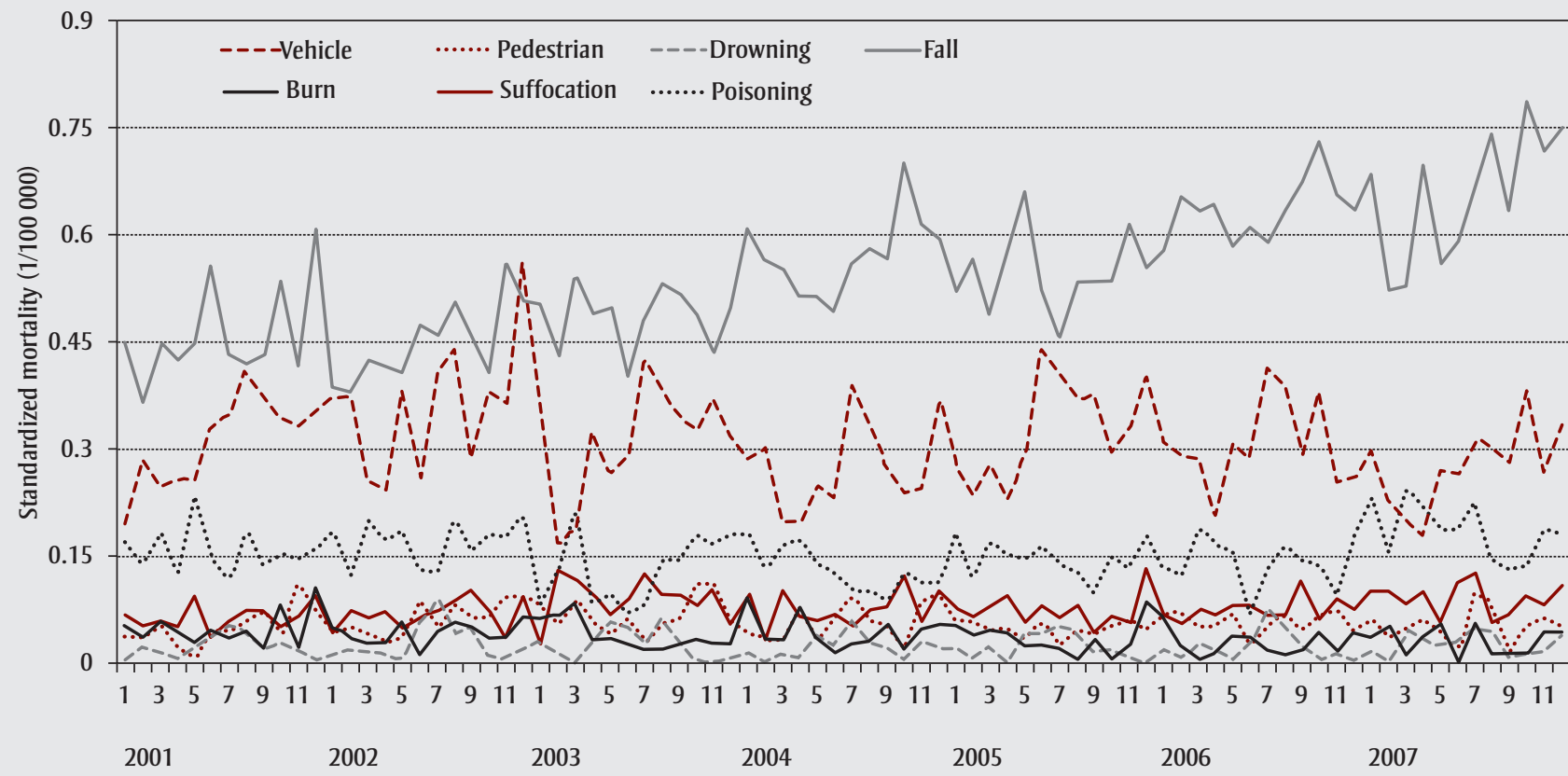

\section{Limitations}

Death registration is mandatory in Canada and therefore there is minimal missing vital statistics data. However, the underlying cause, defined as the disease or injury that initiated the chain of events leading directly to death, is considered. Some people might not die instantly after an injury, and subsequent conditions (e.g. heart failure) might be coded as primary cause of death. This method of death registration relies on medical examiners or coroners' judgment; it may happen that an injury is closely related to the death but is not considered the underlying cause. Since secondary diagnoses are excluded, it may underestimate the true burden of unintentional injury mortality. Miscoding and data entry errors may also result in misclassification of information on cause of deaths and external causes of injuries. In addition, the study period of 7 years is relatively short.

\section{Conclusion}

Overall unintentional injury mortality changed little from year to year while overall mortality showed a steady decline in Canada. The three territories had the highest unintentional injury mortality, both absolutely and as a share of overall mortality. Motor vehicle traffic crashes and falls were the leading causes of injury death. Fall mortality was the only type of unintentional injury mortality that showed an annual increase. Death from fall injury was more common in females than males while other types of injury death were stable and were more common in males than in females. There were seasonal patterns for some types of unintentional injury mortalities such as higher risks of death due to motor vehicle traffic crashes and drowning in summer and falls and burns/fire in winter. The increasing share of overall unintentional injury mortality versus all-cause mortality and the increasing trend for fall mortality call for more research on risk factor identification and effective interventions.

\section{Acknowledgments}

We would like to thank the following for their role in the "Consumer product- related injury and risk assessment” project: Dr. Howard Morrison, senior supervisor and director of the project; Mr. Doug Hopkins, manager of the project; and Ms. Caroline Da Silva, responsible for the management and coordination of the project.

\section{References}

1. Chandran A, Hyder AA, Peek-Asa C. The global burden of unintentional injuries and an agenda for progress. Epidemiol Rev. 2010;32:110-20.

2. Krug EG, Sharma GK, Lozano R. The global burden of injuries. Am J Public Health. 2000;90:523-6.

3. Peden MM, McGee K, Krug E, editors. Injury: a leading cause of the global burden of disease, 2000. Geneva (CH): World Health Organization; 2002.

4. Violence, injuries and disability biennial report, 2006-2007. Geneva (CH): World Health Organization; 2008.

5. Mulholland E; Advisory Committee on the Economic Burden of Injury in Canada. The economic burden of injury in Canada. Toronto (ON): SMARTRISK; 2009.

6. Harrison JE. Injury classification: balancing continuity and utility. Inj Control Safety Promot. 2000;7:51-63. 
7. Curry AE, Hafetz J, Kallan MJ, Winston FK, Durbin DR. Prevalence of teen driver errors leading to serious motor vehicle crashes. Accid Anal Prev. 2011;43:1285-90.

8. Kannus P, Parkkari J, Niemi S, Palvanen M. Fall-induced deaths among elderly people. Am J Public Health. 2005;95:422-4.

9. Statistics Canada. Annual Demographic Estimates: Canada, Provinces and Territories [Internet]. Ottawa (ON): 2011 Sep. [Statistics Canada, Catalogue No.: 91215-X]. Available from: http://www.statcan .gc.ca/pub/91-215-x/91-215-x2011000-eng.htm

10. Statistics Canada. Annual Demographic Statistics, 2005. Ottawa (ON): 2006. [Statistics Canada, Catalogue No.: CS91213/2005].

11. Mo D. Injury mortality risk assessment and targeting the subpopulations for prevention in the Northwest Territories, Canada. Int J Circumpolar Health. 2001;60:391-9.

12. Harrop AR, Brant RF, Ghali WA, Macarthur C. Injury mortality rates in Native and nonNative children: a population-based study. Public Health Rep. 2007;122:339-46.

13. Stevenson MR, Wallace LJ, Harrison J, Moller J, Smith RJ. At risk in two worlds: injury mortality among indigenous people in the US and Australia, 1990-92. Aust N Z J Public Health. 1998;22:641-4.

14. Rauh MJ, Nichols JF, Barrack MT. Relationships among injury and disordered eating, menstrual dysfunction, and low bone mineral density in high school athletes: a prospective study. J Athl Train. 2010;45:243-52.

15. Sakai A, Oshige T, Zenke Y, Yamanaka Y, Otsuka H, Nakamura T. Shorter unipedal standing time and lower bone mineral density in women with distal radius fractures. Osteoporos Int. 2009;21:733-9.

16. Sone T. [Increase in bone mineral density and its effect on fracture risk]. Clin Calcium. 2005;15:625-9.

17. Hartholt KA, Stevens JA, Polinder S, van der Cammen TJ, Patka P. Increase in fallrelated hospitalizations in the United States, 2001-2008. J Trauma. 2011;71: 255-8.
18. Hartholt KA, van Beeck EF, Polinder S, van der Velde N, van Lieshout EM, Panneman $\mathrm{MJ}$, et al. Societal consequences of falls in the older population: injuries, healthcare costs, and long-term reduced quality of life. J Trauma. 2011;71:748-53.

19. Melton LJ 3rd, Riggs BL. Risk factors for injury after a fall. Clin Geriatr Med. 1985;1:525-39.

20. Hartikainen S, Lonnroos E, Louhivuori K. Medication as a risk factor for falls: critical systematic review. J Gerontol A Biol Sci Med Sci. 2007;62:1172-81.

21. Finkelstein EA, Chen H, Prabhu M, Trogdon JG, Corso PS. The relationship between obesity and injuries among U.S. adults. Am J Health Promot. 2007;21:460-8.

22. Hu HY, Chou YJ, Chou P, Chen LK, Huang N. Association between obesity and injury among Taiwanese adults. Int $\mathrm{J}$ Obes (Lond). 2009;33:878-84.

23. Appleby PN, Allen NE, Roddam AW, Key TJ. Physical activity and fracture risk: a prospective study of 1898 incident fractures among 34,696 British men and women. J Bone Miner Metab. 2008;26:191-8.

24. Gill DP, Zou GY, Jones GR, Speechley M. Injurious falls are associated with lower household but higher recreational physical activities in community-dwelling older male veterans. Gerontology. 2008;54:10615.

25. Belechri M, Petridou E, Trichopoulos D. Bunk versus conventional beds: a comparative assessment of fall injury risk. J Epidemiol Community Health. 2002;56:413-7.

26. Dellinger AM, Boyd RM, Haileyesus T. Fall injuries in older adults from an unusual source: entering and exiting a vehicle. J Am Geriatr Soc. 2008;56:609-14.

27. O’Neil J, Steele GK, Huisingh C, Smith GA. Escalator-related injuries among older adults in the United States, 1991-2005. Accid Anal Prev. 2008;40:527-33.

28. Stevens JA, Thomas K, Teh L, Greenspan AI. Unintentional fall injuries associated with walkers and canes in older adults treated in U.S. emergency departments. J Am Geriatr Soc. 2009;57:1464-9.
29. Centers for Disease Control and Prevention (CDC). Fall-related injuries during the holiday season-United States, 2000-2003. MMWR Morb Mortal Wkly Rep. 2004;53:1127-9.

30. Jacobsen SJ, Sargent DJ, Atkinson EJ, O'Fallon WM, Melton LJ 3rd. Contribution of weather to the seasonality of distal forearm fractures: a population-based study in Rochester, Minnesota. Osteoporos Int. 1999;9:254-9.

31. Wareham K, Johansen A, Stone MD, Saunders J, Jones S, Lyons RA. Seasonal variation in the incidence of wrist and forearm fractures, and its consequences. Injury. 2003;34:219-22.

32. Miech R, Koester S, Dorsey-Holliman B. Increasing US mortality due to accidental poisoning: the role of the baby boom cohort. Addiction. 2010;106:806-15.

33. Yoon YH, Stinson FS, Yi HY, Dufour MC. Accidental alcohol poisoning mortality in the United States, 1996-1998. Alcohol Res Health. 2003;27:110-8.

34. Kivisto JE, Parkkari J, Mattila VM, Hoppu K. Poisoning deaths among Finnish children from 1969 to 2003. Acta Paediatr. 2009;98:1661-6.

35. Meyer S, Eddleston M, Bailey B, Desel H, Gottschling S, Gortner L. Unintentional household poisoning in children. Klin Padiatr. 2007;219:254-70. 